\title{
Comparison of PCR methods for detection of Leishmania siamensis infection
}

\author{
Atitaya Hitakarun', Peerapan Tan-ariya' ${ }^{1}$, Suradej Siripattanapipong ${ }^{2}$, Mathirut Mungthin², Phunlerd Piyaraj ${ }^{2}$, \\ Tawee Naaglor ${ }^{2}$, Padet Siriyasatien ${ }^{3}$, Saruda Tiwananthagorn ${ }^{4}$ and Saovanee Leelayoova ${ }^{2^{*}}$
}

\begin{abstract}
Background: Leishmania siamensis, a newly identified species, has been reported as a causative agent of leishmaniasis in Thailand. This organism has been identified and genetically characterized using PCR techniques based on several target genes. However, the sensitivities and specificities of these methods for the diagnosis of $L$. siamensis infection have never been evaluated.

Methods: To evaluate the sensitivities and specificities of PCR methods to detect L. siamensis infection, PCR for different genetic markers, i.e., the small subunit ribosomal RNA region (SSU-rRNA), the internal transcribed spacer 1 region (ITS1), cysteine protease B (cpb), cytochrome b (cyt b), heat shock protein 70 (hsp70), the spliced leader mini-exon, and the triose-phosphate isomerase (tim) genes were compared.

Results: Both the ITS1-PCR and the SSU rRNA-PCR could detect promastigote of L. siamensis at concentrations as low as 0.05 parasites $/ \mu$ l or the DNA concentration at $2.3 \mathrm{pg} / \mu \mathrm{l}$. Though the ITS1-PCR method only recognized 8 samples as positive, all of these could be assessed as true positive according to microscopic diagnosis and/or amplifying the results of the PCR and their sequencing, while other methods also produced false positive results. Compared with the ITS1-PCR method, the PCR amplified SSU-rRNA and cpb gene showed $100 \%$ sensitivity for the detection of $L$. siamensis in clinical specimens. The PCR amplified mini-exon and $h s p 70$ gene also gave a high sensitivity of $87.5 \%$. In contrast, the PCR methods for cyt b and tim gene showed low sensitivity. The PCR methods for cyt b, mini-exon and tim gene showed 100\% specificity compared with the ITS1-PCR.

Conclusion: As a result, the ITS1-PCR method is a suitable target for PCR-based detection of L. siamensis infection in clinical specimens due to its high sensitivity and specificity. The results of this study can be used for molecular diagnosis as well as in epidemiological studies of $L$. siamensis in affected areas.
\end{abstract}

Keywords: Leishmania siamensis, Polymerase chain reaction, Sensitivity, Specificity, The internal transcribed spacer 1 region

\section{Background}

Leishmaniasis, one of the most important vector-borne diseases, has been reported worldwide with an estimated 500,000 new cases and more than 50,000 deaths per year [1]. Leishmania siamensis, a species recently reported in Thailand, causes both cutaneous and visceral leishmaniasis especially in patients with immunocompromised conditions such as HIV/AIDS [2-6]. In addition, leishmaniasis caused by $L$. siamensis was also reported in animals [7-9].

\footnotetext{
*Correspondence: s_leelayoova@scientist.com

${ }^{2}$ Department of Parasitology, Phramongkutklao College of Medicine, Bangkok 10400, Thailand

Full list of author information is available at the end of the article
}

Conventional diagnostic methods based on microscopic examination as well as parasite cultures from clinical specimens such as buffy coat, bone marrow and spleen aspirates show a limited sensitivity $[10,11]$. Serological diagnostic methods also give a high sensitivity; however cross-reactivity could occur with other kinetoplastid parasites. These methods also fail to distinguish between past and present infection [12]. Accordingly, PCR methods have been widely used to detect Leishmania infection in clinical specimens with a high sensitivity and specificity [13]. Several PCR approaches have been published based on different target genes, i.e., the cysteine protease B (cpb) [14], the cytochrome b (cyt b) [15], the 
internal transcribed spacer 1 (ITS1) region of the small subunit ribosomal RNA (SSU-rRNA) gene [16], the glucose-6-phosphate dehydrogenase (G6PD) [17], the heat shock protein 70 (hsp70) [18], the spliced leader mini-exon [19], the SSU-rRNA gene [20] and the triose-phosphate isomerase (tim) genes [21]. Of these, the ITS1 region of the SSU-rRNA gene has been one of the common genetic markers used to detect Leishmania species in the Old World [13,16,22-24].

L. siamensis have been identified and genetically characterized using several target genes [2-6]. However, diagnosis of L. siamensis infection using PCR methods based on different genetic markers has never been evaluated. Thus, this study aimed to compare the sensitivity and specificity of different PCR methods, i.e., the $c p b$, the $c y t \mathrm{~b}$, the hsp70, the spliced leader mini-exon, the SSU-rRNA, the tim and the ITS1-PCR method.

\section{Methods}

\section{Leishmania parasite}

Promastigotes of L. siamensis (MHOM/TH/2010/TR), harvested from axenic culture in Schneider's Drosophila medium, supplemented with $20 \%$ fetal bovine serum (FBS), were used in this study [25]. Promastigotes were centrifuged at 2,000 $\mathrm{g}$ for $15 \mathrm{~min}$, washed three times with phosphate buffered saline (PBS), and resuspended in $1 \mathrm{ml}$ of PBS. Numbers of parasites were counted and calculated using a hemocytometer. DNA was extracted using Illustra tissue \& cells genomic Prep Mini Spin Kit (GE Healthcare, UK). DNA extraction from promastigotes of L. donovani strain MHOM/SD/68/1S (Biomedical Research, Amsterdam, The Netherlands) was also performed and used as a reference strain in this study. All extracted DNA samples were stored at $-20^{\circ} \mathrm{C}$ until used.

\section{PCR assay}

Table 1 shows different primer pairs used to detect $L$. siamensis in this study, which amplified different target genes, i.e., the $c p b$, the $c y t b$, the ITS1 region of the SSUrRNA, the $h s p 70$, the spliced leader mini-exon, the SSUrRNA and the tim gene. To amplify the cyt $b$ [15], the ITS1 region of SSU-rRNA [16], the mini-exon [19] and the SSU-rRNA gene [20], the previously described primer pairs were used. For the $h s p 70$ gene, the HSP70senKS primer was designed and replaced the HSP70sen of the reported primer set (HSP70sen/HSP70ant) [18] to increase the sensitivity to detect $L$. siamensis. In addition, new primer pairs for the $c p b$ (LH-CPBEF-F2/LH-CPBEF-R) and tim (TIM-F/TIM-R) gene were designed and used in this study.

All PCR methods were performed at a final volume of $50 \mu \mathrm{l}$, containing $25 \mathrm{pmol}$ of each primer, $0.2 \mathrm{mM}$ dNTP, $2 \mathrm{mM} \mathrm{MgCl}_{2}$, 1x PCR buffer, $1.5 \mathrm{U}$ of Taq DNA polymerase and $1 \mu \mathrm{l}$ of DNA template, using the optimal annealing temperature (Table 1). Extracted DNA from normal human blood was used as the internal control and distilled water was used as the negative control. Expected amplicons of PCR products were visualized using electrophoresis at $100 \mathrm{~V}$ on $1.5 \%$ agarose gel mixed with $\mathrm{SYBR}^{\bullet}$ Safe DNA gel stain (Invitrogen, USA) in $1 \mathrm{X}$ Tris Borate EDTA (TBE) buffer.

\section{Detection limit of PCR methods}

Detection limit of all PCR methods was performed to detect $L$. siamensis. Ten-fold serial dilutions were performed to obtain samples containing 500, 50, 5, 0.5, 0.05, and 0.005 parasites/ $\mu \mathrm{l}$. DNA was then extracted using Illustra tissue \& cells genomic Prep Mini Spin Kit (GE Healthcare, UK). Further PCR steps were performed using $1 \mu \mathrm{l}$ of DNA template, containing the equivalent of the above

Table 1 PCR methods and primers used in this study

\begin{tabular}{|c|c|c|c|c|c|}
\hline Target gene & Primer set & Primer sequence $5^{\prime}-3^{\prime}$ & Annealing $\left({ }^{\circ} \mathrm{C}\right)$ & Expected amplicon size (bp) & Ref. \\
\hline \multirow[t]{2}{*}{ ITS1 } & L5.8S & TGA TAC CAC TTA TCG CAC TT & 53 & 348 & [13] \\
\hline & LITSR & CTG GAT CAT TIT CCG ATG & & & \\
\hline \multirow[t]{2}{*}{$c p b$} & LH-CPBEF-F2 & TGC GGS TCS TGC TGG GCS TTC & 59 & 525 & This study \\
\hline & LH-CPBEF-R & GCG SAY GTA SCC CTT CTC RC & & & \\
\hline \multirow[t]{2}{*}{ cyt $b$} & L.Cyt-S & GGT GTA GGT TTT AGT YTA GG & 55 & 900 & [12] \\
\hline & L.cyt-R & CTA CAA TAA ACA AAT CAT AAT ATR CAA TT & & & \\
\hline \multirow[t]{2}{*}{ hsp70 } & HSP70senKS & GAC GGT GCC KGC STA CTT CAA & 61 & 1422 & [15], This study \\
\hline & HSP70ant & CCG CCC ATG CTC TGG TAC ATC & & & \\
\hline \multirow[t]{2}{*}{ mini-exon } & Fme & TAT TGG TAT GCG AAA CTT CCG & 54 & 540 & [16] \\
\hline & Rme & ACA GAA ACT GAT ACT TAT ATA GCG & & & \\
\hline \multirow[t]{2}{*}{ SSU-rRNA } & S4 & GAT CCA GCT GCA GGT TCA CC & 67 & 540 & [17] \\
\hline & $\mathrm{S} 12$ & GGT TGA TTC CGT CAA CGG AC & & & \\
\hline \multirow[t]{2}{*}{ tim } & TIM-F & TCA ACG AKC ATC AGA TCG AC & 53 & 500 & This study \\
\hline & TIM-R & ATC TTC TCG CTC ACC CAC TG & & & \\
\hline
\end{tabular}


dilutions. Another set of DNA templates was also used. DNA concentration was measured using a Nano Drop spectrophotometer (ND-1000 model, Thermo Scientific, USA). Ten-fold serial dilutions of the extracted DNA were then performed to obtain the DNA concentration at $23,000,2,300,230,23,2.3$, and $0.23 \mathrm{pg} / \mu \mathrm{l}$. One microliter of each concentration was used as DNA template for PCR amplification. The most sensitive method was defined as the method that could amplify the DNA extracted from the lowest number of promastigotes or the lowest DNA concentration of $L$. siamensis. In addition, DNA samples of Trypanosoma brucei, T. cruzi, T. evansi, Trichomonas vaginalis, Giardia intestinalis, Plasmodium falciparum, and Entamoeba histolytica were also test for the specificity of each PCR method.

\section{Sensitivities and specificities of PCR methods to detect L. siamensis}

All 7 PCR methods were then evaluated for their sensitivities and specificities to detect L. siamensis in 42 clinical specimens. These clinical samples were sent to the Department of Parasitology, Phramongkutklao College of Medicine for microscopic and PCR diagnosis of leishmaniasis. Most samples were collected from the patients who presented with fever, hepatosplenomegaly and pancytopenia at tertiary hospitals in the South, the endemic areas of leishmaniasis in Thailand. Extracted DNA of 42 clinical samples from patients including buffy coat, bone marrow and tissue biopsy (one skin biopsy) were used. Of these, eight samples were assessed as true positive according to the results of the PCR amplifying the ITS1 region of the SSU-rRNA gene and their sequencing. Thirty four samples were considered as true negative because ITS1-PCR showed negative result. Of eight positive samples, three samples from bone marrow aspiration and one sample of skin biopsy were microscopically positive for amastigotes and ITS1-PCR positive for Leishmania. The other four positive samples were diagnosed by ITS1-PCR amplification using buffy coat samples. All eight samples were confirmed as $L$. siamensis infection by DNA sequencing of the ITS1 region of the SSU-rRNA gene. Sensitivities and specificities of six PCR methods to detect $L$. siamensis were determined comparing to the ITS1-PCR method.

\section{DNA sequencing}

All positive PCR products from any PCR assays were confirmed for $L$. siamensis sequence identity. Bidirectional DNA sequencing was performed by the 1st Base Pte., Ltd., Singapore. Nucleotide sequences were validated using the Bioedit Program version 7.0.1.

\section{Statistical analysis}

Sensitivities, specificities and positive and negative predictive values were calculated using two-by-two tables and StataCorp. 2009, Stata Statistical Software: Release 11. College Station, TX: StataCorp LP.

\section{Ethics statement}

This study was approved by the Ethics Committee of the Royal Thai Army Medical Department, Thailand. No information on the patients was presented in this study.

\section{Results}

\section{Detection limits of PCR methods}

Table 2 shows the detection limit of the seven PCR methods. In this study, the ITS1- and the SSU-rRNAPCR were the most sensitive methods that could detect L. siamensis at the concentration as low as $2.3 \mathrm{pg} / \mu \mathrm{l}$ or 0.05 parasites/ $\mu l$. In contrast, five other PCR methods could amplify when higher concentrations of L. siamensis DNA were applied. The PCR method amplifying the ITS1 region of $L$. siamensis showed the amplicon of $348 \mathrm{bp}$, while amplifying $L$. donovani DNA generated the amplicon of 319 bp.

\section{Cross-amplification of PCR methods using DNA of other parasites}

We determined the cross-amplification of these seven PCR methods using the DNA of other parasites. PCR amplifications of the mini-exon and the tim genes amplified no other parasites' DNA (Table 3). The PCR method for the $c y t b$ gene showed cross-amplification with $T$. brucei DNA. Both PCR methods targeting the SSU-rRNA and hsp70 genes could amplify the DNA of T. brucei, and T. evansi. The PCR method for the $c p b$ gene amplified all the DNA of flagellates used in this study. The L5.8S/LITSR primers amplifying the ITS1 region could not amplify DNA of other parasites at $348 \mathrm{bp}$. A band at $600 \mathrm{bp}$ appeared when amplifying T. evansi DNA. However, in contrast to the cross reactions produced by the other PCR methods, the positive band of $T$. evansi could easily be differentiated from that of $L$. siamensis by their distinctive sizes.

\section{Sensitivities and specificities of PCR methods to detect L. siamensis in clinical samples}

Table 4 shows the sensitivities, specificities and positive (PPVs) and negative predictive values (NPVs) of six PCR methods compared with the ITS1-PCR to detect $L$. siamensis in clinical samples. PCR amplification of the ITS1 region rated 8 samples as positive, amplification of the $c p b$ gene rated 24 samples as positive, both amplification of the SSU-rRNA and the $h s p 70$ gene rated 14 samples as positive. DNA sequencing was performed for all positive PCR amplification. False positive was considered when the results of DNA sequencing were not compatible to $L$. siamensis. From these results, PCR amplification of the SSUrRNA and the $c p b$ gene showed the sensitivity of $100 \%$. 
Table 2 The detection limit of seven PCR methods for the detection of $L$. siamensis

\begin{tabular}{|c|c|c|c|c|c|c|c|c|c|c|c|c|}
\hline \multirow{3}{*}{$\begin{array}{l}\text { Target } \\
\text { gene }\end{array}$} & \multicolumn{12}{|c|}{ PCR results by } \\
\hline & \multicolumn{6}{|c|}{ Number of parasites/ $\left.\mu\right|^{*}$} & \multicolumn{6}{|c|}{ DNA concentration $(\mathrm{pg} / \mu \mathrm{l})$} \\
\hline & 500 & 50 & 5 & 0.5 & 0.05 & 0.005 & 23000 & 2300 & 230 & 23 & 2.3 & 0.23 \\
\hline ITS1 & + & + & + & + & + & - & + & + & + & + & + & - \\
\hline$c p b$ & + & + & + & - & - & - & + & + & + & - & - & - \\
\hline cyt $b$ & + & + & + & - & - & - & + & + & + & - & - & - \\
\hline hsp70 & + & + & + & + & - & - & + & + & + & + & - & - \\
\hline mini-exon & + & + & + & + & - & - & + & + & + & + & - & - \\
\hline SSU-rRNA & + & + & + & + & + & - & + & + & + & + & + & - \\
\hline tim & + & + & + & + & - & - & + & + & + & + & - & - \\
\hline
\end{tabular}

*Ten-fold serial dilutions were performed to obtain samples containing 500, 50, 5, 0.5, 0.05 and 0.005 promastigotes/ $\mu$ l before DNA extraction.

Both PCR method for the mini-exon and the $h s p 70$ genes showed the sensitivity of $87.5 \%$. PCR method for the $c y t b$ gene showed the lowest sensitivity for the detection of $L$. siamensis. The specificity of $100 \%$ was also observed for PCR amplified the $c y t b$, the mini-exon and the tim gene.

\section{Discussion}

The present study showed that the PCR amplifying the ITS1 region of SSU-rRNA gene (L5.8S/LITSR) was the most accurate method to detect $L$. siamensis. Though only 8 samples were recognized as positive, all of these could be assessed as true positive according to microscopic diagnosis and/or amplifying the results of the PCR and their sequencing, while other methods also produced false positive results. To date, there is still no gold standard technique for the diagnosis of leishmaniasis. Thus, the sensitivities and the specificities of other six PCR methods were determined by comparing to the ITS1-PCR method. Our result was similar to a recent study that tested the ITS1-PCR method in L. donovani [26]. This method could detect the promatigote of $L$. siamensis as low as 0.05 parasites/ $\mu$ l or a DNA concentration at $2.3 \mathrm{pg} / \mu \mathrm{l}$. For clinical samples, $100 \%$ of L. siamensispositive samples (eight samples) were identified by this method. Using the ITS1 region of the SSU-rRNA gene as the target for PCR showed a high sensitivity because approximately 20-400 copies of the SSU-rRNA gene per Leishmania genome exist [27-29]. The ITS1-PCR method can also differentiate $L$. siamensis from $L$. donovani in a single-tube PCR. The DNA of $L$. siamensis was detected at $348 \mathrm{bp}$ whereas that of $L$. donovani was shown at 319 bp. Additionally, this primer pair could not amplify the DNA of other protozoa parasites, except T. evansi, which was detected at $600 \mathrm{bp}$. A study in Brazil also showed a cross-amplification of the ITS1-PCR method in $T$. cruzi showing the amplicon at 700 bp [30]. However, $L$. siamensis and T. evansi can be clearly discriminated by the size of their amplicons. The ITS1-PCR method also gave a negative result when human DNA was used as the internal control (data not shown).

The detection limit of S4/S12, the primer pair targeting the SSU-rRNA gene was compatible with the ITS1-PCR method. Although the SSU-rRNA PCR showed 100\% sensitivity to detect L. siamensis in clinical samples, false positive results could be detected in six samples. DNA sequencing of these PCR products indicated that this primer pair could amplify human DNA. In addition, the S4/ S12 primers could also amplify the DNA of other flagellate protozoa, i.e., T. brucei and T. evansi and gave the amplicon at $563 \mathrm{bp}$. Thus, the SSU-rRNA PCR method to diagnose Leishmania infection in clinical specimens should be used with caution and the positive PCR products have to

Table 3 Comparison of cross-amplification of seven PCR methods

\begin{tabular}{|c|c|c|c|c|c|c|c|}
\hline \multirow{2}{*}{$\begin{array}{l}\text { Target } \\
\text { gene }\end{array}$} & \multicolumn{7}{|c|}{ PCR results } \\
\hline & T. brucei & T. cruzi & T. evansi & T. vaginalis & G. intestinalis & P. falciparum & E. histolytica \\
\hline ITS1 & - & - & + & - & - & - & - \\
\hline$c p b$ & + & + & + & + & + & - & - \\
\hline cyt b & + & - & - & - & - & - & - \\
\hline hsp70 & + & - & + & - & - & - & - \\
\hline mini-exon & - & - & - & - & - & - & - \\
\hline SSU-rRNA & + & - & + & - & - & - & - \\
\hline tim & - & - & - & - & - & - & - \\
\hline
\end{tabular}




\begin{tabular}{|c|c|c|c|c|c|c|c|}
\hline \multirow[t]{3}{*}{ Method } & \multirow[t]{3}{*}{ Result } & \multicolumn{2}{|c|}{ L. siamensis } & \multirow{3}{*}{$\begin{array}{l}\text { Sensitivity \% } \\
(95 \% \mathrm{Cl})\end{array}$} & \multirow{3}{*}{$\begin{array}{l}\text { Specificity \% } \\
(95 \% \mathrm{Cl})\end{array}$} & \multirow{3}{*}{$\begin{array}{l}\text { PPV \% } \\
(95 \% \mathrm{Cl})\end{array}$} & \multirow{3}{*}{$\begin{array}{l}\text { NPV \% } \\
(95 \% \mathrm{Cl})\end{array}$} \\
\hline & & +ve & -ve & & & & \\
\hline & & no. (\%) & no. (\%) & & & & \\
\hline \multirow[t]{2}{*}{$c p b$} & + ve & $8(100.0)$ & $16(47.1)$ & $100(63.1-100.0)$ & $52.9(35.1-70.2)$ & $33.3(15.6-55.3)$ & $100(81.5-100.0)$ \\
\hline & -ve & $0(0)$ & 18 (52.9) & & & & \\
\hline \multirow[t]{2}{*}{$c y t b$} & + ve & $3(37.5)$ & $0(0)$ & $37.5(8.52-75.5)$ & 100 (89.7-100.0) & $100(29.2-100.0)$ & $87.2(72.6-95.7)$ \\
\hline & -ve & $5(62.5)$ & $34(100.0)$ & & & & \\
\hline \multirow[t]{2}{*}{ hsp70 } & + ve & $7(87.5)$ & $7(22.8)$ & 87.5 (47.3-99.7) & $79.4(62.1-91.3)$ & $50(23.0-77.0)$ & 96.4 (81.7-99.9) \\
\hline & -ve & $1(12.5)$ & $27(77.2)$ & & & & \\
\hline \multirow[t]{2}{*}{ mini-exon } & + ve & $7(87.5)$ & $0(0)$ & 87.5 (47.3-99.7) & 100 (89.7-100.0) & $100(59.0-100.0)$ & 97.1 (85.1-99.9) \\
\hline & -ve & $1(12.5)$ & $34(100.0)$ & & & & \\
\hline \multirow[t]{2}{*}{ SSU-rRNA } & + ve & $8(100.0)$ & $6(17.6)$ & $100(63.1-100.0)$ & $82.4(65.5-93.2)$ & $57.1(28.9-82.3)$ & $100(87.7-100.0)$ \\
\hline & -ve & $0(0)$ & $28(82.4)$ & & & & \\
\hline \multirow[t]{2}{*}{ tim } & +ve & $4(50)$ & $0(0)$ & $50(15.7-84.3)$ & $100(90.7-100.0)$ & $100(39.8-100.0)$ & 90.5 (77.4-97.3) \\
\hline & -ve & $4(50)$ & $38(100.0)$ & & & & \\
\hline
\end{tabular}

+ve, positive, - ve, negative.

be confirmed by sequence analysis. Another disadvantage of the SSU-rRNA PCR method is that it cannot differentiate among the different species of Leishmania [13,25,30,31].

The Fme/Rme primer set, amplifying the mini-exon gene [19], could detect $L$. donovani at the DNA concentration as low as $10 \mathrm{pg} / \mu \mathrm{l}$. The limit of this primer set to detect $L$. siamensis was in the same range as previously reported in $L$. donovani [32]. The mini-exon gene contains 100-200 copies in the nuclear Leishmania genome, consisting of transcribed conserved and non-transcribed variable regions [32]. These regions differ among Leishmania species. Thus, it could be used to differentiate Leishmania species. For clinical specimens, this primer set showed the sensitivity of $87.5 \%$ for the detection of L. siamensis. Although a previous study showed a crossspecies amplification in T. cruzi, T. brucei, and Crithidia fasciculata [33], no amplification in a wide range of parasites and also human DNA was found in this study.

Montalvo et al. [34] reported a primer set specific to the $h s p 70$ to detect Leishmania. This primer set showed different detection limits in different Leishmania subgenera. In the present study, the HSP70sen/HSP70ant primer set could amplify the DNA of L. siamensis at the lowest concentration of $230 \mathrm{pg} / \mu \mathrm{l}$. Therefore, the HSP70senKS primer was designed and replaced the HSP70sen to increase the sensitivity showing the detection limit at $23 \mathrm{pg} /$ $\mu \mathrm{l}$. However, this newly designed as well as the previously described primer pairs [34] could detect other hemoflagellates. False positive result might also limit the use of HSP70 PCR. DNA sequencing of 7 false positive PCR products showed that the HSP70 PCR could amplify human DNA as well.
The cpbEF-frd/cpbEF-rev primer set has been used to amplify the $c p b$ gene of Leishmania species, both $L$. donovani and L. infantum $[35,36]$. However, this primer set could not amplify the DNA of L. siamensis. Therefore, a new primer set (LH-CPBEF-F2/LH-CPBEF-R) was designed based on the $c p b$ sequence data of all Leishmania species reported in GenBank. This new primer set amplified L. siamensis DNA and showed 100\% sensitivity, equivalent to the ITS1 and SSU-rRNA PCR methods. Unfortunately, LH-CPBEF-F2/LH-CPBEF-R primer set could amplify the DNA of other flagellate parasites including T. brucei, T. cruzi, T. evansi, T. vaginalis and G. intestinalis. Among all tested PCR methods, the LH-CPBEF-F2/LH-CPBEF-R primer set gave the lowest specificity to detect $L$. siamensis in clinical specimens.

To date, the information on tim gene are limited because only a small number of sequences of Leishmania species were reported in GenBank. In the present study, a new set of primers amplifying the tim gene has been designed which could amplify Leishmania at the concentration as low as 0.5 parasites/ $\mu$ l or a DNA concentration at $23 \mathrm{pg} / \mu \mathrm{l}$. However, the sensitivity of tim-PCR method was still lower compared with the ITS1-PCR method. The L.cyt-S/L.cyt-R primer set for the PCR method amplifying the $c y t b$ gene also showed a low sensitivity at $37.5 \%$. Thus, these two PCR methods might not be suitable for the screening of $L$. siamensis infection.

The limitation of this study was that the number of patients/clinical samples used in this study was rather small and the 95\%-CIs were therefore extremely wide. Increased accuracy of these tests may need a larger sample size. However, the acquisition of sufficient positive 
samples can be a troublesome labor and maybe the acquisition of higher number samples of this newly recognized parasite species was not possible.

\section{Conclusion}

Among these tested PCR methods, the ITS1-based method is the most sensitive and suitable to diagnose leishmaniasis caused by $L$. siamensis. This PCR method could differentiate $L$. siamensis and $L$. donovani by their amplicon sizes in a single-tube PCR. Due to its high sensitivity, this method would be useful for the epidemiological survey of $L$. siamensis infection in Thailand.

\section{Competing interests}

The authors declare that they have no competing interests.

\section{Authors' contributions}

AH, PT, MM, PS, ST and SL contributed to the conception and design of the study. TN and SL maintained the parasites. AH and SS performed molecular techniques. $\mathrm{AH}$ and PP analyzed the data. $\mathrm{AH}, \mathrm{MM}$ and $\mathrm{SL}$ wrote the manuscript. All authors read and approved the final version that was submitted for publication.

\section{Acknowledgement}

This study was financially supported by Phramongkutklao College of Medicine.

\section{Author details}

'Department of Microbiology, Faculty of Science, Mahidol University, Ratchawithi Rd., Ratchathewi, Bangkok 10400, Thailand. 'Department of Parasitology, Phramongkutklao College of Medicine, Bangkok 10400, Thailand. ${ }^{3}$ Department of Parasitology, Faculty of Medicine, Chulalongkorn University, Bangkok 10330, Thailand. ${ }^{4}$ Department of Veterinary Biosciences and Veterinary Public Health, Faculty of Veterinary Medicine, Chiang Mai University, Chiang Mai 50100, Thailand.

Received: 17 June 2014 Accepted: 21 September 2014

Published online: 02 October 2014

\section{References}

1. WHO: Leishmaniasis Magnitude of The Problem. Available from: http://www.who.int/leishmaniasis/burden/magnitude/burden_magnitude/ en/print.html.

2. Sukmee T, Siripattanapipong S, Mungthin M, Worapong J, Rangsin R, Samung Y, Kongkaew W, Bumrungsana K, Chanachai K, Apiwathanasorn C, Rujirojindakul P, Wattanasri S, Ungchusak K, Leelayoova S: A suspected new species of Leishmania, the causative agent of visceral leishmaniasis in a Thai patient. Int J Parasitol 2008, 38:617-622.

3. Suankratay C, Suwanpimolkul G, Wilde H, Siriyasatien P: Autochthonous visceral leishmaniasis in a human immunodeficiency virus (HIV)-infected patient: the first in thailand and review of the literature. Am J Trop Med Hyg 2010, 82:4-8.

4. Bualert $L$, Charungkiattikul W, Thongsuksai $P$, Mungthin $M$, Siripattanapipong S, Khositnithikul R, Naaglor T, Ravel C, El Baidouri F, Leelayoova S: Autochthonous disseminated dermal and visceral leishmaniasis in an AIDS patient, southern Thailand, caused by Leishmania siamensis. Am J Trop Med Hyg 2012, 86:821-824.

5. Chusri S, Hortiwakul T, Silpapojakul K, Siriyasatien P: Consecutive cutaneous and visceral leishmaniasis manifestations involving a novel Leishmania species in two HIV patients in Thailand. Am J Trop Med Hyg 2012, 87:76-80.

6. Osatakul S, Mungthin M, Siripattanapipong S, Hitakarun A, Kositnitikul R, Naaglor T, Leelayoova S: Recurrences of visceral leishmaniasis caused by Leishmania siamensis after treatment with amphotericin B in a seronegative child. Am J Trop Med Hyg 2014, 90:40-42.

7. Müller N, Welle M, Lobsiger L, Stoffel MH, Boghenbor KK, Hilbe M, Gottstein B, Frey CF, Geyer C, von Bomhard W: Occurrence of Leishmania sp. in cutaneous lesions of horses in Central Europe. Vet Parasitol 2009, 166:346-351.
8. Lobsiger L, Müller N, Schweizer T, Frey CF, Wiederkehr D, Zumkehr B Gottstein B: An autochthonous case of cutaneous bovine leishmaniasis in Switzerland. Vet Parasitol 2010, 169:408-414

9. Reuss SM, Dunbar MD, Calderwood Mays MB, Owen JL, Mallicote MF, Archer LL, Wellehan JF Jr: Autochthonous Leishmania siamensis in horse, Florida, USA. Emerg Infect Dis 2012, 18:1545-1547.

10. Piarroux R, Gambarelli F, Dumon H, Fontes M, Dunan S, Mary C, Toga B, Quilici M: Comparison of PCR with direct examination of bone marrow aspiration, myeloculture, and serology for diagnosis of visceral Leishmaniasis in immunocompromised patients. J Clin Microbio/ 1994, 32:746-749.

11. Ozerdem D, Eroglu F, Genc A, Demirkazik M, Koltas IS: Comparison of microscopic examination, rK39, and PCR for visceral leishmaniasis diagnosis in Turkey. Parasitol Res 2009, 106:197-200.

12. Romero HD, de LA S, Silva-Vergara ML, Rodrigues V, Costa RT, Guimarães SF, Alecrim W, Moraes-Souza H, Prata A: Comparative study of serologic tests for the diagnosis of asymptomatic visceral leishmaniasis in an endemic area. Am J Trop Med Hyg 2009, 81:27-33.

13. Schönian G, Nasereddin A, Dinse N, Schweynoch C, Schallig HD, Presber W Jaffe CL: PCR diagnosis and characterization of Leishmania in local and imported clinical samples. Diagn Microbiol Infect Dis 2003, 47:349-358.

14. Hide M, Bañuls AL: Species-specific PCR assay for L. infantum/L. donovani discrimination. Acta Trop 2006, 100:241-245.

15. Luyo-Acero GE, Uezato H, Oshiro M, Takei K, Kariya K, Katakura K, GomezLandires E, Hashiguchi Y, Nonaka S: Sequence variation of the cytochrome $\mathrm{b}$ gene of various human infecting members of the genus Leishmania and their phylogeny. Parasitology 2004, 128:483-491.

16. El Tai NO, El Fari M, Mauricio I, Miles MA, Oskam L, El Safi SH, Presber WH, Schönian G: Leishmania donovani: intraspecific polymorphisms of Sudanese isolates revealed by PCR-based analyses and DNA sequencing. Exp Parasitol 2001, 97:35-44.

17. Castilho TM, Shaw JJ, Floeter-Winter LM: New PCR assay using glucose-6phosphate dehydrogenase for identification of Leishmania species. J Clin Microbiol 2003, 41:540-546.

18. Garcia L, Kindt A, Bermudez H, Llanos-Cuentas A, De Doncker S, Arevalo J, Wilber Quispe Tintaya K, Dujardin JC: Culture-independent species typing of neotropical Leishmania for clinical validation of a PCR-based assay targeting heat shock protein 70 genes. J Clin Microbiol 2004, 42:2294-2297.

19. Marfurt J, Niederwieser I, Makia ND, Beck HP, Felger I: Diagnostic genotyping of Old and New World Leishmania species by PCR-RFLP. Diagn Microbiol Infect Dis 2003, 46:115-124.

20. Uliana SR, Nelson K, Beverley SM, Camargo EP, Floeter-Winter LM: Discrimination amongst Leishmania by polymerase chain reaction and hybridization with small subunit ribosomal DNA derived oligonucleotides. J Eukaryot Microbiol 1994, 41:324-330.

21. Kushawaha PK, Gupta R, Tripathi CD, Khare P, Jaiswal AK, Sundar S, Dube A: Leishmania donovani triose phosphate isomerase: a potential vaccine target against visceral leishmaniasis. PLoS One 2012, 7:e45766.

22. Amro A, Gashout A, Al-Dwibe H, Zahangir Alam M, Annajar B, Hamarsheh O, Shubar H, Schönian G: First molecular epidemiological study of cutaneous leishmaniasis in Libya. PLoS Negl Trop Dis 2012, 6:e1700.

23. Mahdy MA, Al-Mekhlafi HM, Al-Mekhlafi AM, Lim YA, Bin Shuaib NO, Azazy AA, Mahmud R: Molecular characterization of Leishmania species isolated from cutaneous leishmaniasis in Yemen. PLoS One 2010, 5:e12879.

24. Yehia L, Adib-Houreih M, Raslan WF, Kibbi AG, Loya A, Firooz A, Satti M, El-Sabban M, Khalifeh I: Molecular diagnosis of cutaneous leishmaniasis and species identification: analysis of 122 biopsies with varied parasite index. J Cutan Pathol 2012, 39:347-355.

25. Leelayoova S, Siripattanapipong S, Hitakarun A, Kato H, Tan-ariya P, Siriyasatien P, Osatakul S, Mungthin M: Multilocus characterization and phylogenetic analysis of Leishmania siamensis isolated from autochthonous visceral leishmaniasis cases, southern Thailand. BMC Microbio/ 2013, 13:60.

26. Khan MG, Bhaskar KR, Kikuchi M, Salam MA, Akther T, Haque R, Mondal D, Hamano S: Comparison of PCR-based diagnoses for visceral leishmaniasis in Bangladesh. Parasitol Int 2014, 63:327-331.

27. Leon W, Fouts D, Manning J: Sequence arrangement of the $16 \mathrm{~S}$ and $26 \mathrm{~S}$ rRNA genes in the pathogenic haemoflagellate Leishmania donovani. Nucl Acids Res 1978, 5:491-503.

28. Villalba E, Ramirez JL: Ribosomal DNA of Leishmania brasiliensis: number of ribosomal copies and gene isolation. J Protozool 1982, 29:438-441. 
29. Inga R, De Doncker S, Gomez J, Lopez M, Garcia R, Le Ray D, Arevalo J, Dujardin JC: Relation between variation in copy number of ribosomal RNA encoding genes and size of harbouring chromosomes of Leishmania of subgenus Viannia. Mol Biochem Parasitol 1998, 92:219-228.

30. Bensoussan E, Nasereddin A, Jonas F, Schnur LF, Jaffe CL: Comparison of PCR assays for diagnosis of cutaneous leishmaniasis. J Clin Microbiol 2006, 44:1435-1439.

31. van Eys GJ, Schoone GJ, Kroon NC, Ebeling SB: Sequence analysis of small subunit ribosomal RNA genes and its use for detection and identification of Leishmania parasites. Mol Biochem Parasitol 1992, 51:133-142.

32. Roelfsema JH, Nozari N, Herremans T, Kortbeek LM, Pinelli E: Evaluation and improvement of two PCR targets in molecular typing of clinical samples of Leishmania patients. Exp Parasitol 2011, 127:36-41.

33. Harris E, Kropp G, Belli A, Rodriguez B, Agabian N: Single-step multiplex PCR assay for characterization of New World Leishmania complexes. J Clin Microbiol 1998, 36:1989-1995.

34. Montalvo AM, Fraga J, Maes I, Dujardin JC, Van der Auwera G: Three new sensitive and specific heat-shock protein 70 PCRs for global Leishmania species identification. Eur J Clin Microbiol Infect Dis 2012, 31:1453-1461.

35. Hide M, Bras-Gonçalves R, Bañuls AL: Specific cpb copies within the Leishmania donovani complex: evolutionary interpretations and potential clinical implications in humans. Parasitology 2007, 134:379-389.

36. Gadisa E, Kuru T, Genet A, Engers H, Aseffa A, Gedamu L: Leishmania donovani complex (Kinetoplastida, Trypanosomatidae): comparison of deoxyribonucleic acid based techniques for typing of isolates from Ethiopia. Exp Parasitol 2010, 126:203-208.

doi:10.1186/s13071-014-0458-x

Cite this article as: Hitakarun et al.: Comparison of PCR methods for detection of Leishmania siamensis infection. Parasites \& Vectors 2014 7:458.

\section{Submit your next manuscript to BioMed Central and take full advantage of:}

- Convenient online submission

- Thorough peer review

- No space constraints or color figure charges

- Immediate publication on acceptance

- Inclusion in PubMed, CAS, Scopus and Google Scholar

- Research which is freely available for redistribution

Submit your manuscript at www.biomedcentral.com/submit
() Biomed Central 